\title{
Stosunki Unia Europejska - Chiny w XXI wieku
}

\section{Wprowadzenie}

W 2014 roku nakładem Wydawnictwa Instytutu Studiów Politycznych Polskiej Akademii Nauk ukazało się pierwsze wydanie książki pod moją redakcją naukową, pt. Unia Europejska - Chiny. Dziś i w przyszłości, która spotkała się z życzliwym przyjęciem wśród czytelników. O dużym zainteresowaniu tą publikacją świadczy fakt, iż jej pierwszy nakład szybko zniknął z półek księgarń, co dziś w dobie Internetu i kryzysu czytelnictwa zdarza się w naszym kraju dość rzadko. Co więcej, spotkała się też ona z licznymi i bardzo dobrymi recenzjami, które ukazały się na łamach prestiżowych periodyków naukowych w Polsce (,Przegląd Politologiczny”, 2016, s. 205-207; „Studia Europejskie”, 2014, s. 191-198; „Studia Polityczne”, 2014, s. 170-174; „Myśl Ekonomiczna i Polityczna", 2014, s. 332-336).

$\mathrm{Na} ł a m a c h$ niniejszego artykułu spróbuję pokazać obecne szanse i zagrożenia dla obu tych aktorów na arenie międzynarodowej oraz ich wzajemne relacje dziś i w przyszłości. Ponadto spróbuję zweryfikować kontrowersyjną - moim zdaniem - hipotezę, lansowaną przez wielu badaczy, a która zakłada, że wiek XXI będzie wiekiem Azji, czyli de facto Chin. Omawiając bowiem Azję w kategoriach potęgi, w pierwszym rzędzie trzeba mieć na uwadze Chiny, gdyż zgodnie z teorią Organskiego dotyczącą „tranzycji potęgi”, to właśnie Chiny najsilniej zaburzą ład międzynarodowy. Otóż tysiące lat imperialnej przeszłości, kultura polityczna, światopogląd, ogrom terytorium i wielka liczba ludności, dotychczasowe sukcesy gospodarcze, odporność na światowy kryzys finansowy - wszystko to przemawia za tym, że Chiny wkrótce odzyskają status mocarstwa światowego, jaki utraciły w połowie XIX wieku. Póki co, nie są jednak ożywione misjonarskim duchem, który był jednym z czynników motywujących zachodnie przedsięwzięcia imperialne (Buhler, 2014, s. 475). Fareed Zakaria pisze, że: „Wystarczy im, że są tym, czym są, a zdobycie statusu światowego mocarstwa w pewnym sensie stanowi wypełnienie ich historycznej roli” (Zakaria, 2009, s. 140).

Nasuwa się tutaj pytanie, czy droga jaką podążają Chiny po śmierci Mao Zedonga i reformach zapoczątkowanych w 1979 roku przez Deng Xiaopinga stanowią alternatywę dla demokracji i kapitalizmu liberalnego? I tak i nie, bowiem demokracja i kapitalizm mimo wielu problemów, wciąż mają się dobrze i dominują na świecie, a komunistyczne Chiny w praktyce stosuja jego zasady i mechanizmy gospodarcze. Dzięki temu położone zostały ekonomiczne fundamenty potęgi, których brak było Chinom pod rządami dogmatycznego Mao Zedonga: fundamenty przemysłowe, dzięki czemu Chiny stały się „fabryką świata”, oraz fundamenty handlowe i finansowe - kraj ten stał się głównym ośrodkiem wymiany na świecie. Wszechstronnie otwarte na świat, Chiny dokładają starań, by dorównać mu pod względem nowoczesności: nadrabia- 
ją zaległości technologiczne, kształcą setki tysięcy studentów za granicą i dziesiątki milionów w kraju, rozwijają przedsiębiorstwa wielonarodowe, przejmują obce firmy, przyswajają sobie techniki soft power itd. (Łoś, 2017, s. 37-57).

Chiński model gospodarczy i imponujący rozwój wpływają na pozytywne postrzeganie ChRL. Obecnie Chiny są postrzegane jako kraina dobrobytu, zwłaszcza przez ludzi z krajów biednych, gdzie american dream zdaje się być nieosiagalny, natomiast ten chiński jest w zasięgu ręki. Przykład chiński pokazuje, że gospodarka może się rozwijać bez funkcjonowania liberalnej demokracji. Ale takie widzenie rozwoju jest groźne dla wartości Zachodu, także dla UE, gdyż oznacza, że wzrost gospodarczy i oparcie na nim potęgi oraz dobrobytu można osiagnąć bez demokracji (Łoś, 2017, s. 37-57; Leonard, 2008, s. 96-98).

Gospodarka chińska bez watpienia jest nośnikiem soft power, ale jej siła wpływa również na rozwój innych elementów potęgi Chiny modernizują swoją armię, zwłaszcza lotnictwo strategiczne i marynarkę wojenną oraz budują nowoczesne lotniskowce. Jednocześnie Pekin realizuje dobrze przemyślaną i ostrożną strategię, by minimalizować nieuniknione negatywne efekty uboczne wzrostu potęgi Chin. Świadomy niepokoju i reakcji, jakie fakt ten może wzbudzać w Azji i na świecie, podejmuje liczne kroki, by wykazać bezzasadność percepcji „chińskiego zagrożenia”. Stosując zalecenia Sun Tzu - „odmawiać walki, gdy przeciwnik jest zbyt potężny” - chińscy przywódcy unikają konfrontacji ze Stanami Zjednoczonymi, które mogłyby się poczuć najbardziej zagrożone w swej pozycji światowego mocarstwa, a których przewaga militarna jest tak przytłaczająca, że wyperswadowuje wszelką awanturniczość. Zarazem systematycznie sprawdzają jak daleko mogą się posuwać, w szczególności energicznie ponawiając od 2010 roku roszczenia do suwerenności nad obszarami morskimi i budując instalacje wojskowe na zajętych prawem kaduka wysepkach na Morzu Południowochińskim. Amerykanie nadal patrolują te wody (Buhler, 2014, s. 477; Warszawski, 2017, s. 11).

Natomiast w relacjach z mocarstwami azjatyckimi, zwłaszcza z Japonią i Indiami, które bezpośrednio odczuwają wzrost potęgi Chin, stosunek sił jest znacznie bardziej korzystny dla Pekinu, co sprawi, że niekiedy zapomina on o niezbędnej ostrożności. Od połowy lat dziewięćdziesiątych XX wieku chińscy przywódcy starali się, aby zwalczać wszelkie uprzedzenia w stosunku do ChRL, ale od 2009 zaczęli prowadzić coraz bardziej asertywną politykę, która niepokoi nie tylko ich sąsiadów, ale także Stany Zjednoczone, które dokładają starań, by zintegrować Chiny z istniejącym międzynarodowym systemem, który wciąż jeszcze same kontrolują. Kolejni prezydenci Stanów Zjednoczonych, łącznie z Donaldem Trumpem podkreślają korzyści, jakie ma to dla Chin i jednocześnie przestrzegają je przed konsekwencjami, na jakie by się naraziły, starając się ten system obalić. Dał temu wyraz D. Trump także podczas ostatniego szczytu G-7 w Taorminie na Sycylii w dniach 26-27 maja 2017 roku. Ale przywódcy Chin wiedza, że Donald Trump musi zmienić swój kurs, jeśli chce „szybko rozwiązać” - jak obiecał - problem północnokoreański. Bez współpracy z Pekinem tego bowiem nie da się zrobić (Korzycki, 2017, s. 17).

Dziś sytuacja w Chinach i w Unii Europejskiej oraz ich rola na świecie jest już inna, aniżeli kilka lat temu. Są też inne realia międzynarodowe, mniej lub bardziej sprzyjające współpracy Chin i Unii Europejskiej. Świat bowiem wciąż ewoluuje i dy- 
namicznie zmienia swoje oblicze. W ten sposób w praktyce międzynarodowej znajdują swoje uzasadnienie teoria cyklu hegemonicznego Georga Modelskiego, teoria systemów - światów Immanuela M. Wallerstaina oraz teoria zmiany systemu międzynarodowego Roberta Filipina (Fiszer, 2013, s. 13-14; Donelly, 2000, s. 123; Czaputowicz, 2007).

W ciagu trzech ostatnich dekad pozycja, a w ślad za nią rola Chin we współczesnym świecie uległa ogromnemu wzmocnieniu. Wiąże się to z dynamicznym rozwojem ich gospodarki, znaczącemu jej unowocześnieniu oraz z poważnym wzrostem sił obronnych. Natomiast Unia Europejska przeżywa głęboki kryzys polityczny, gospodarczy, imigracyjny i ma wiele innych problemów, które ograniczają jej rolę na arenie światowej polityki. W UE doszło do delegitymizacji wszystkich opcji, w opozycji do których była definiowana idea integracji europejskiej: nacjonalizmu, brutalnej gry potęgi, gier o sumie zerowej, prymatu siły nad prawem itd. Jej wizerunek na świecie zblakł. Znika też nadzieja na to, że zjednoczona Europa zajmie jedno z centralnych miejsc w kształtującym się na naszych oczach nowym ładzie globalnym. Ale, jak pisze francuski politolog i dyplomata Pierre Buhler: „Nie znaczy to, że Europa jest skazana na paraliż. Związki między państwami i Unią są na tyle elastyczne, że pozwalają reagować na sytuacje, które wymagają innego rytmu niż rytm europejskich procedur uzgadniania. Mobilizacja całości to kwestia przywództwa, lecz inicjatywa musi wyjść od członków UE, którzy mają dostateczne zasoby i wpływy, by poprowadzić określoną operację lub politykę wiążącą w oczach świata. Tylko duże państwa, czyli Wielka Brytania, Francja, Niemcy, Włochy i w coraz większej mierze Polska, spełniają te kryteria [...]" (Buhler, 2014, s. 490-491).

Niestety, rzecz w tym, że w Unii Europejskiej mamy do czynienia również z kryzysem przywództwa i brakiem oświeconych elit politycznych. Obecni unijni decydenci, to różnego rodzaju ekspolitycy, byli premierzy, ministrowie, czy działacze partyjni, dla których wysokie stanowiska w Unii, czy fotel eurodeputowanego, to tylko znakomite synekury. W kontekście powyższego zgadzam się z opinią Krzysztofa Szczerskiego, który pisze, że: „Kryzys, jaki dotknął Unię Europejską nie zostanie rozwiązany jakąś pojedynczą, cudowną decyzją. W polityce nie ma czarodziejskich różdżek, potrzeba mądrego przywództwa i sensownej wizji, ale to są akurat towary deficytowe wśród elit decyzyjnych Unii”' (Szczerski, 2017, s. 105).

\section{Postzimnowojenny świat i jego ewolucja w XXI wieku}

Świat po zimnej wojnie, która zakończyła się wraz z rozpadem Związku Radzieckiego i jego bloku w latach 1989-1991, wbrew oczekiwaniom stał się bardzo skomplikowany, pełen nowych wyzwań oraz zagrożeń. Pojawili się nowi aktorzy, w tym Unia Europejska, Federacja Rosyjska oraz reformujące się i coraz bardziej otwierające się na świat Chiny oraz inne mocarstwa wschodzące, które zaliczamy do grupy krajów „BRIC”. Już na początku lat dziewięćdziesiątych XX wieku pojawiła się więc potrzeba ponownego zdefiniowania porządku międzynarodowego i zarysowania jego nowej struktury - tak, aby po latach rywalizacji pomiędzy dwoma wrogimi blokami stworzyć nowy ład międzynarodowy i nie doprowadzić do stanu nierównowagi. Między ponad 
dwustoma uczestnikami stosunków międzynarodowych, państwowych i pozapaństwowych, na początku XXI wieku należało na nowo zredefiniować wzajemne stosunki pomiędzy nimi i oprzeć je na solidnych, demokratycznych podstawach. Trzeba było zbudować nowy, demokratyczny system (ład) międzynarodowy, oparty na mocnych fundamentach. Globalizacja i narastające problemy globalne wręcz wymuszały określone działania (współpracy lub rywalizacji), zwłaszcza w stosunkach między państwami. Jednak triumf „wolnego świata” nad komunizmem wraz z rozpadem Związku Radzieckiego ugruntował przekonanie, błędne, jak się później okazało, że liberalna demokracja jest jedyną rozsądną propozycją stworzenia ekonomiczno-politycznego ładu, co w praktyce miało oznaczać wzmocnienia paradygmatu demokracji deliberacyjnej, definiującej cele polityki w kategoriach konsensu i pojednania. Rzecznicy takiego podejścia dowodzili, że dzięki osłabieniu tożsamości zbiorowych możliwy stał się świat bez wrogów, przemocy i nieprzekraczalnych konfliktów i że dzięki procedurom deliberacyjnym jest możliwość na bieżąco rozwiązywać problemy wynikające z „deficytu demokracji” w stosunkach międzynarodowych. Tak się jednak nie stało. Świat po dwublokowej rywalizacji pomiędzy Stanami Zjednoczonymi i Związkiem Radzieckim został zdominowany w znacznej mierze przez rywalizację i konflikty, a nie stał się - jak głosili wówczas zwolennicy teorii neoliberalizmu - globalną wioską, opartą na zasadach solidarnej współpracy wszystkich aktorów sceny międzynarodowej (Kuźniar, 2016; Wojciechowski, Tomczak, 2010; Guzek, 2014, s. 15-27).

Profesor Marian Guzek, ekonomista znany ze swego krytycznego stosunku do neoliberalizmu trafnie zauważył, że: „Głównym źródłem neoliberalizmu stała się ideologia, której popularność w świecie zachodnim, ale nie tylko zachodnim, z pewnością przewyższyła ideologię komunistyczną. Ta druga była bowiem społeczeństwom narzucana zwykle po zdobyciu władzy przez komunistów i sprawowaniu jej w sposób autokratyczny. Natomiast ideologia neoliberalna była rozpowszechniana w warunkach realizowanego we wszystkich państwach systemu demokratycznego. A najważniejsze jest to, że była wdrażana bez ujawniania jej szczegółowych zasad, lecz pod jednym hasłem wolnego rynku jako synonimu liberalizmu gospodarczego" i dodaje, że neoliberalizm to taki ustrój, w którym ,władza jest sprawowana formalnie przez demokratyczne instytucje państwa, ale ograniczane w ich funkcjach oraz kompetencjach w wyniku uzależnienia od przemysłowych i finansowych korporacji o wielkim potencjale majątkowym. Ustrój ten pojawił się w wersji rozwiniętej w Stanach Zjednoczonych na początku lat 80. XX wieku" (Guzek, 2014, s. 15-16). Ćwierć wieku później, doprowadził on w latach 2008-2012 prawie do bankructwa Stany Zjednoczone i większość państw Europy. Skutki tego kryzysu finansowo-gospodarczego, który de facto wciąż trwa, czego przykładem jest Grecja, boleśnie odczuły także Unia Europejska i w nieco mniejszym stopniu Rosja i Chiny.

Bezprecedensowy wzrost gospodarczy ChRL w trzech ostatnich dekadach z pewnością należy do najistotniejszych procesów na kuli ziemskiej, które zmieniły i nadal zmieniają świat. Chińskie reformy gospodarcze, zapoczątkowane w grudniu 1978 roku przyniosły do końca 2012 roku przeciętny roczny wzrost PKB rzędu 9,8\%. Nigdy w najnowszych dziejach świata żadne państwo nie odnotowało tak wielkich sukcesów przez tak długi czas, a ponieważ chodzi tutaj o najludniejsze państwo świata, zarazem o powierzchni większej niż Stany Zjednoczone czy cała Unia Euro- 
pejska, przesunięcie bogactwa i władzy z Zachodu na Wschód staje się nieuniknione. Rzecz jasna, ta rozwijająca się potęga, jaką stanowią dziś wciąż komunistyczne Chiny, wywarła daleko idący wpływ na ład gospodarczy, na geoekonomię i geopolitykę współczesnego świata (Góralczyk, 2015, s. 40-41; Zadęcki, Borkowski, Wróbel, 2013, s. 139-141).

Niestabilność współczesnego środowiska międzynarodowego pogłębiają liczne konflikty o różnym charakterze: politycznym, religijnym, ideologicznym, społecznym, etnicznym, kulturowym, terytorialnym i ekonomicznym. Na przykład wschód Europy zdominował konflikt na obszarze Ukrainy, podsycany przez Rosję, która sukcesywnie realizuje swoje mocarstwowe aspiracje. Wojna w latach 2014-2015 stawia pytanie o przetrwanie Ukrainy w dotychczasowym kształcie terytorialnym i politycznym. Na ostatnim szczycie NATO w dniach 8-9 lipca 2016 roku w Warszawie, na który zaproszono także prezydenta Ukrainy, oficjalnie po raz kolejny potępiono aneksję Krymu i wezwano Rosję do wycofania militarnego i finansowego poparcia dla separatystów z Donbasu, a nieoficjalnie, podczas kuluarowych spotkań Petro Poroszenki z prezydentem Stanów Zjednoczonych Barackiem Obamą, kanclerz Niemiec Angelą Merkel, prezydentem Francji Francis'em Hallandem i premierem Kanady Justinem Trudeau zachęcano Ukraińców, żeby przyznali większą autonomię Donbasowi, czyli regionowi kontrolowanemu przez separatystów i prowadzili pokojowe rozmowy z Rosją (Wieliński, Wroński, Zawadzki, 2016 s. 4; Winiecki, 2016, s. 12-13).

Zachód, czyli Stany Zjednoczone, NATO i Unia Europejska, nie chce drażnić Rosji, która jest agresorem i złamała wszelkie normy prawa międzynarodowego i de facto Ukrainę pozostawia samotna, na łasce Władimira Putina, który próbuje rozmontować pozimnowojenny porządek, z punktu widzenia Rosji głęboko niesprawiedliwy, bo spychający ją na pozycję mocarstwa regionalnego. Dziwną, bo ambiwalentną postawę wobec wojny rosyjsko-ukraińskiej zajęła także ChRL, która po zakończeniu zimnej wojny oficjalnie opowiada się za pokojowym, multipolarnym i multicywilizacyjnym porządkiem globalnym. W latach 90 . XX wieku Chiny przystapiły do kilku reżimów międzynarodowych, przede wszystkim dotyczących broni masowego rażenia. Stały się członkiem APEC (1991 r.), a także rozpoczęły regularne spotkania z członkami ASEAN (1996 r.). Od 2000 roku działa Forum Współpracy Chiny-Afryka, a rok później ChRL uzyskała członkostwo w Światowej Organizacji Handlu oraz stała się członkiem-założycielem Szanghajskiej Organizacji Współpracy. Chiny biorą też co roku udział w spotkaniach grupy BRICS (Brazylia, Rosja, Indie, Chiny i od 2011 roku Afryka Południowa) począwszy od 2006 roku. Podobnie jak w przypadku Afryki, relacje z krajami Europy Środkowo-Wschodniej przybrały od 2012 roku postać regularnych spotkań (tzw. format 16+1). Szczególną rolę Chiny przywiązują wciąż do ONZ, biorą udział w misjach pokojowych pod oenzetowską flagą, aktywnie uczestniczą w przekazywaniu pomocy humanitarnej dla krajów dotkniętych klęskami żywiołowymi i wojną. Ta wzmożona aktywność Chin w forach międzynarodowych szła w parze z deklaracjami chińskich przywódców, gdzie multilateralizm zajmował szczególne miejsce, zwłaszcza w kwestiach związanych z bezpieczeństwem i gospodarką. W praktyce zaś, konflikty międzynarodowe, które osłabiają Zachód czy Rosję, sprzyjają umacnianiu pozycji Chin na arenie międzynarodowej. Tymczasem w planach Władimira Putina 
odbudowy Rosji jako supermocarstwa globalnego ważną rolę ma odegrać wspomniana wyżej Ukraina (Fiszer, 2016, s. 15-39; Kuźniar, 2015, s. 63-85; Świder, 2015, s. 181-249).

Sytuację Ukrainy pogarsza kryzys finansowy, kosztowna wojna, która mimo podpisanego rozejmu, wciąż trwa oraz niebotyczna korupcja i narastający tam od wiosny 2016 roku kryzys polityczny, który wyraźnie wskazuje na niepowodzenie działalności kół rządzących państwem, czołowych partii politycznych i poszczególnych polityków wspieranych przez prezydenta Ukrainy Petro Poroszenkę oraz ich niezdolność do spełnienia swoich wyborczych obietnic i zobowiązań. Wielu badaczy podkreśla, że poziom i skala korupcji politycznej na Ukrainie osiągnęły w 2016 roku niepokojące rozmiary i stanowi to zagrożenie dla samego istnienia państwa w warunkach prowadzonej przez Rosje ,wojny hybrydowej”, a obecny system polityczny w tym kraju charakteryzują ponadto kleptokracja, korupcja, lobbing i zaniechanie celów długoterminowych. Związki korupcyjne wykazują tendencję przejścia na poziom dominującej normy zachowania elit. W warunkach słabej państwowości, niestabilnego porządku prawnego - korupcja na Ukrainie staje się specyficzną formą stosunków między rządem a obywatelami. Wszystko to generuje głębokie podziały społeczne, ogranicza kształtowanie się społeczeństwa obywatelskiego i hamuje rozwój kraju (Borkowski, 2016, s. 67-79; Bielecki, 2014, s. 12).

Obawa przed kolejnymi działaniami Rosji, szczególnie o charakterze wojny hybrydowej, jest dziś widoczna także w postradzieckich krajach bałtyckich oraz w Polsce. W związku z tym, brytyjski generał Richard Shirreff, do 2014 roku zastępca naczelnego dowódcy sił NATO w Europie, wzywa obecnie, by Sojusz zamiast skupiać się na zapewnieniach dla państw bałtyckich i Polski, powinien koncentrować wysiłki na budowaniu potencjału odstraszania potencjalnego wroga. Jest to - jego zdaniem - niezbędne, gdyż czeka nas wojna, którą Rosja zacznie w państwach bałtyckich i dodaje, że: „To kraj, który nie cofa się przed zmianą granic w Europie przy użyciu siły i rozwija potencjał wojskowy wystarczający do tego, by narzucić swoją wolę sąsiadom. Inwazja Krymu pokazała, że nie doceniliśmy i nie rozumieliśmy nastawienia Rosji” (Winiecki, 2016, s. 13; Wieliński, 2016, s. 4-5).

W podobnym duchu w ostatnich miesiącach wypowiadali się też amerykańscy wojskowi, m.in. generał Ben Hodges, głównodowodzący amerykańskich wojsk lądowych, który w rozmowie z tygodnikiem „Die Zeit” stwierdził, że Rosja „byłaby w stanie podbić państwa bałtyckie szybciej, niż my je obronić" i potwierdził oceny rosyjskich wojskowych, wedle których Rosjanie mogliby podbić państwa bałtyckie w ciagu 36-60 godzin (Kokot, 2016, s. 5).

Powyższe ostrzeżenia doprowadziły wreszcie do swoistego przebudzenia NATO, które na warszawskim szczycie podjęło decyzję o rozmieszczeniu na wschodniej flance czterech batalionów i zawarło strategiczne porozumienie z Unią Europejską, na mocy którego obie organizacje zobowiązały się do koordynacji ćwiczeń w obronie przed atakami hybrydowymi oraz opracowania reguł współpracy w tego typu kryzysach. Prezydent Stanów Zjednoczonych podczas tego szczytu podkreślał, że realizuje swoje obietnice z 4 czerwca 2014 roku. Mianowicie, po agresji Rosji na Ukrainę w przemówieniu wygłoszonym w Warszawie 4 czerwca 2014 roku zapowiedział on, że Polska i kraje bałtyckie nie będą same. Wtedy po raz pierwszy na 
tereny Polski i krajów bałtyckich skierowano kontyngenty armii amerykańskiej (na początek kompanię spadochroniarzy) oraz innych państw NATO. Teraz zaś, zdecydowano o „stałej rotacyjnej obecności” czterech grup batalionowych (po 1 tys. żołnierzy) w Polsce, na Litwie, Łotwie i w Estonii od 2017 r. Ponadto zapowiedziano rozmieszczenie amerykańskiej brygady pancernej na wschodniej flance NATO, której dowództwo będzie znajdowało się w Polsce. Z pewnością decyzje te zwiększą bezpieczeństwo Europy, narażonej na imperialne zakusy Rosji (Wroński, 2016, s. 1; Bielecki, Zawadzki, 2016, s. 3).

Natomiast południe Europy i de facto cała Unia Europejska zmaga się z ogromnymi falami imigracyjnymi, będącymi konsekwencją destabilizacji sytuacji w krajach Afryki Północnej i na Bliskim Wschodzie (Szpak, 2015, s. 111-132). Jak pokazuje obecny kryzys migracyjny, nie jest możliwe rozwianie tego problemu przez jednostronne posunięcia, takie na przykład, jak wzmocnienie granic i niewpuszczanie migrantów lub uchodźców. Należy pamiętać, że każda osoba wnioskująca o status uchodźcy ma prawo (zgodnie z Konwencją o statusie uchodźców z 1951 r.) do zbadania swojego wniosku. Nikogo nie można odesłać do państwa, w którym grożą mu lub jej tortury lub jego/jej życie może być zagrożone. Istotne jest więc oddzielenie uchodźców od migrantów ekonomicznych, gdyż obowiązek udzielenia pomocy obejmuje tylko tych pierwszych.

Coraz gorsze są też stosunki Turcji z Rosją i Turcji z Unią Europejską. Ankara, zamiast do Europy się zbliżać, coraz bardziej się od niej oddala, zarówno jeśli idzie o standardy demokratyczne, poszanowanie wolności słowa i mediów, jak i laickości państwa. Jeszcze nie tak dawno Turcja deklarowała politykę "zero problemów z sąsiadami", a dziś ma problemy z każdym z nich, w tym z Unią Europejską. Generuje to, obok nasilającego się terroryzmu międzynarodowego, wzrost populizmu oraz nastrojów ksenofobicznych i nacjonalistycznych w Europie i na świecie. To zaś utrudnia rozwiązanie kryzysu imigracyjnego w Europie. Nasilają się procesy dezintegracyjne w Unii Europejskiej i podziały w NATO, co osłabia bezpieczeństwo całego Zachodu, a jednocześnie sprzyja umacnianiu się na świecie roli Chin i pozostałych mocarstw zaliczanych do grupy BRIC (Radziwinowicz, 2016), s. 10).

Condoleezza Rice, doradca ds. bezpieczeństwa narodowego Stanów Zjednoczonych w dobie rządów prezydenta George’a W. Busha i za jego drugiej kadencji szefowa amerykańskiej dyplomacji, a dziś profesor na Uniwersytecie w Stanfordzie będąc niedawno w Warszawie przypomniała obawy, które na Zachodzie słychać coraz częściej, a mianowicie, że świat, który powstał po II wojnie światowej, a którego NATO jest głównym filarem, zaczyna się chwiać, czego objawy widać także w Polsce. Ten światowy porządek miała gwarantować amerykańska potęga militarna i wspólna obrona, zgodnie z artykułem piątym Traktatu Waszyngtońskiego. Dziś ten porządek jest poddawany próbom, na które nie został przygotowany. M.in. atakowany jest przez samozwańcze państwo ISIS, ale też Chiny i Rosja próbują skorzystać z okazji i osłabić rolę Zachodu, a zwłaszcza Stanów Zjednoczonych na świecie, spychając je na pozycję potęgi drugiej kategorii. Europejscy populiści lansują radykalne rozwiązania polityczne, społeczne i gospodarcze o charakterze antysystemowym; odrzucają wolny rynek i globalizację w obecnym kształcie oraz występują przeciwko imigracji i w ogóle przeciwko Unii Europejskiej (Winiecki, 2016, s. 13). 


\section{Unia Europejska i jej obecne problemy jako bariery w relacjach z Chinami}

Obserwując bieżącą sytuację międzynarodową, można zauważyć, że Unia Europejska przeżywa bardzo poważny kryzys, a wielość problemów, które musi rozwiązać, powoduje, że nie sposób oprzeć się wrażeniu, że projekt europejski stoi obecnie przed bardzo poważnym wyzwaniem własnej, głębokiej przebudowy. Po sukcesach (choć raczej pozornych, jak się wydaje z dzisiejszej perspektywy) pierwszej dekady XXI wieku, związanych z wprowadzeniem wspólnej waluty euro i akcesjami postkomunistycznych państw Europy Środkowo-Wschodniej i Południowej, Unia Europejska dziś musi się zmierzyć z problemami pojawiającymi się w konsekwencji ogólnoświatowego kryzysu finansowo-gospodarczego, a ostatnio także bardzo niepokojących wydarzeń na arenie międzynarodowej, których skutki są silnie odczuwane zarówno wewnątrz Unii, jak i u jej granic, od fal uchodźców oraz wyniku brytyjskiego referendum począwszy, na mnożących się atakach terrorystycznych wewnątrz Unii skończywszy. Sytuacja na Ukrainie u wschodnich granic UE, a także nowy układ sił na arenie międzynarodowej, jaki kształtuje się po zaprzysiężeniu nowego prezydenta Stanów Zjednoczonych, również nie są czynnikami sprzyjającymi stabilizacji wewnątrz struktur wspólnotowych i euroatlantyckich. W dodatku kwestie te niejako nałożyły się na problemy istniejące w UE już wcześniej, jeszcze mocniej je uwypuklając. Wielu analityków europejskiego procesu integracji od lat wskazywało bowiem na stale obecny w tym procesie problem legitymizacyjnych braków instytucji europejskich, nadmiernie elitarnego charakteru idei integracji oraz nieprzejrzystych europejskich procedur, również w tym upatrując przyczyn współczesnego mega kryzysu Unii (Heise, 2014; Abbas, Förster, Richter, 2015; Szymańska, 2016, s. 19-20).

Unia Europejska bowiem dziś jednocześnie przeżywa - obok kryzysu finansowo-gospodarczego i imigracyjnego - najcięższy w swojej historii kryzys polityczny i strukturalny. Ma coraz większy kłopot z demokracją. Maleje solidarność silnych ze słabszymi, zwiększają się problemy z implementacją prawa europejskiego, co przyczynia się do jego wymuszania pod presją polityczną i ekonomiczną. Rośnie upolitycznienie Komisji Europejskiej i swobodna interpretacja prawa unijnego przez tę instytucję. Osłabia to wiarygodność instytucji i prawa europejskiego, które dotąd były fundamentem dla integracji w Europie. Po raz pierwszy jeden z największych krajów unijnych - Wielka Brytania postanowiła opuścić Unię Europejską. Brexit jest interpretowany jako bunt społeczeństwa przeciwko establishmentowi i jego liberalnej polityce gospodarczej. I choć przynosi ona korzyści Wielkiej Brytanii, to nie rozkładają się one równo wśród społeczeństwa. Rośnie dziś w Unii Europejskiej, także w Wielkiej Brytanii grupa przegranych - osób starszych, gorzej wykształconych, spoza wielkich metropolii. To one zagłosowały za Brexitem. Skutki Brexitu mogą być katastrofalne dla Unii Europejskiej, gdyż może to być początek jej końca. Podobne tendencje widać już coraz wyraźniej w innych krajach członkowskich, m.in. we Francji, Holandii, na Węgrzech, w Republice Czeskiej, a także w Niemczech. Według ostatniego badania Pew Reaserch Center aż 61\% Francuzów ma nieprzychylną opinię wobec Unii, a tylko $38 \%$ pozytywną (Grosse, 2016, s. A11).

Brexit, kryzysy finansowo-gospodarczy i migracyjny obnażyły również wiele innych słabości Unii Europejskiej, a zwłaszcza bezsilność technokratycznego zarządza- 
nia unijnymi politykami oraz ujawniły faktyczne ośrodki władzy w skomplikowanym unijnym systemie politycznym, w którym codzienna działalność nie zawsze wskazuje na pierwszy rzut oka centra podejmowania kluczowych decyzji. Przede wszystkim ujawniły słabość decyzyjną czołowego organu ponadnarodowego Unii Europejskiej, czyli Komisji Europejskiej. Kryzysy te, bezprecedensowe w najnowszych dziejach Europy i UE, pokazały również słabość czynnika międzyrządowego oraz istniejące wciąż w Unii Europejskiej podziały, egoizmy i partykularyzmy. W większości krajów Europy obywatele stracili do niej zaufanie, a proces dezintegracji nasila się. Dzieje się tak dlatego, że UE już od dawna nie ma charyzmatycznych przywódców, wizjonerów ani wybitnych polityków. Kierują nią dziś biurokraci i partyjni działacze, oderwani od obywateli i ich potrzeb, a jej system polityczny jest ułomny i wymaga głębokiej modernizacji, a nie tylko kosmetycznych zmian. Musi się on zmienić i to jak najszybciej. Unia Europejska chcąc przetrwać musi ewoluować w kierunku państwa obywatelskiego i socjalnego (Fiszer, 2014, s. 101-124; Ruszkowski, Wojnicz, 2013; Wierzchowska, 2016; Żakowski, 2016, s. 12-14).

Mimo narastającego eurosceptycyzmu i populizmu, Europejczycy - i to w zdecydowanej większości - nadal pragną pokoju, dobrobytu, demokracji, równości i stabilnego rozwoju gospodarczego, ale są w stanie mniej poświęcić, aby te dobra osiagnąć. Europejska solidarność i wzajemne zaufanie uległy bowiem - jak już wspominałem - poważnym naruszeniom, a przecież są to wartości, których budowa trwa długo, ale jeśli się utrwalą są poważnym potencjałem dla rozwoju korzystnej współpracy. Natomiast ich poważne zakwestionowanie skutkuje długotrwałą modyfikacją wzajemnych relacji. Unia Europejska właśnie weszła w taki stan wzajemnego braku zaufania i osłabienia ducha solidarności. Jak trafnie zauważa Anna Wierzchowska: „Kryzys systemowy opanował wiele dziedzin współpracy i nakręca spiralę negatywnych zjawisk w procesie integracji. Hamuje także szanse dla podjęcia efektywnych działań modernizacyjnych, które muszą »przebijać się« przez przeszkody, restrykcyjne rozwiązania wprowadzane w związku z zarządzaniem antykryzysowym i wreszcie spadek zaufania dla integracji europejskiej rosnący wśród obywateli. Dynamika zmian wyraźnie spada, szczególnie jeśli spojrzymy na komponent modernizacji, który współtworzy system zmiany w procesie integracji europejskiej. Rezultatem jest modyfikacja zarządzania procesem integracyjnym. Przewaga zjawisk kryzysowych wymusza bowiem działania naprawcze, które często mają charakter krótkoterminowy lub dotyczą wybranej grupy państw, zagrożonej kryzysem" (Wierzchowska, 2016, s. 449).

Unia Europejska, aby powstrzymać tendencje dezintegracyjne powinna zmienić dotychczasową politykę neoliberalną na rzecz polityki prospołecznej i zrewidować politykę oszczędności oraz zwiększyć skalę inwestycji w państwach słabiej rozwijających się lub pogrążonych w kryzysie. Ponadto, powinna wreszcie rozwiązać problem deficytu demokracji w Europie, czyli wprowadzić pełną demokrację w UE poprzez ustanowienie federacji demokratycznych państw narodowych, lub oddanie kompetencji unijnych z powrotem do państw członkowskich, czyli tam gdzie istnieje demokratyczna kontrola nad władzą. Niestety, oba te kierunki zmian są mało prawdopodobne w najbliższych latach. Bogate państwa są bowiem niechętne zwiększaniu transferów finansowych na rzecz małych i średnich państw, a jednocześnie odrzucają ideę federacji i opowiadają się za współpracą międzyrządową państw UE. Przywód- 
cy Unii Europejskiej odrzucają też możliwość rewizji unijnych traktatów. W związku z tym, zapewne nastapi zacieśnienie kolejnych reżimów gospodarczych i politycznych, zwłaszcza tych, które przynoszą korzyści najsilniejszym państwom UE, czyli po wyjściu z niej Wielkiej Brytanii, Niemiec i Francji. Pociagnie to za sobą ekspansję prawa unijnego, ale bez konieczności zmiany dotychczasowych traktatów. W tym też kierunku zmierzają propozycje ministrów spraw zagranicznych Francji i Niemiec - Franka-Waltera Steinmeiera i Jeana-Marca Ayraulta, przesłane tuż po Brexicie pozostałym członkom UE. Postulują oni pogłębienie integracji w niektórych obszarach, m.in. w polityce obronnej i migracyjnej oraz wzmocnienie strefy euro (Grosse, 2016, s. 13; Ein starkes Europa in einer unsicheren Welt von Jean-Marc Ayrault und FrankWalter Steinmeier, 2014).

Nie ulega wątpliwości, że przetrwanie wszystkich implikacji referendum w Wielkiej Brytanii długo jeszcze będzie absorbować ten kraj, Europę i cały świat. Najgłębsze konsekwencje Brexitu będą oczywiście zależeć od reakcji Unii Europejskiej na wycofanie się z niej Wielkiej Brytanii. Warto w tym miejscu przytoczyć opinię profesora Josepha Stiglitza, laureata Nagrody Nobla w dziedzinie ekonomii, który pisze: „Każdy rząd w UE za cel pierwszej wagi powinien obecnie uważać poprawę pomyślności zwykłych obywateli. Zwiększona dawka ideologii neoliberalnej w tym nie pomoże. Powinniśmy też przestać mylić wyniki ze środkami. Na przykład wolny handel, gdyby dobrze nim pokierować, mógłby przynieść większe korzyści wszystkim. Jeśli jednak dobrze się nim nie pokieruje, spowoduje obniżenie poziomu życia licznych obywateli, a być może ich większości. [...] Istnieją przecież rozwiązania alternatywne w stosunku do obecnych układów neoliberalnych. Niektóre z nich mogą tworzyć podzielany przez wszystkich dobrobyt, ale są również takie, które - jak proponowane przez byłego prezydenta USA, Baracka Obamę, Transatlantyckie Partnerstwo w sprawie Handlu i Inwestycji - mogą wyrządzić jeszcze większe szkody. Wyzwaniem na dziś jest wyciagnięcie lekcji z przeszłości - tak żeby zaakceptować pierwsze z tych rozwiązań i zapobiec drugiemu" (Stiglitz, 2017).

\section{Unia Europejska w polityce międzynarodowej Chin}

Współczesne stosunki międzynarodowe w dynamicznie zmieniającym się świecie, w którym następuje powrót do czasów wielobiegunowości i multilateralizmu, obfitują w rozliczne i wieloaspektowe zagrożenia dla pokoju i bezpieczeństwa międzynarodowego. Dotychczasowi, czołowi strażnicy globalnego status quo, a zwłaszcza Stany Zjednoczone i Unia Europejska, pogrążeni w kryzysie przywództwa i tracący z wolna - na rzecz wschodzących potęg - globalną hegemonię, nie są w stanie zapewnić sobie i światu bezpieczeństwa. W dobie lawinowo narastających konfliktów (w szczególności tych asymetrycznych, m.in. terroryzmu międzynarodowego) żadne państwo, nawet najbardziej potężne Stany Zjednoczone, czy Chiny nie są w stanie sprostać powyższym zagrożeniom. Dlatego dziś potrzeba zacieśniania współpracy międzynarodowej jest priorytetowym zadaniem dla wszystkich podmiotów stosunków międzynarodowych, tak państwowych, jak i pozapaństwowych. Tylko od samej społeczności międzynarodowej zależy, czy walcząc o pokój i bezpieczeństwo, wybierze ona wspólne 
działania, czy też rywalizację, która - jak pokazuje to historia stosunków międzynarodowych - prędzej czy później prowadzi do zwiększenia ilości konfliktów i chaosu międzynarodowego oraz do wojny „wszystkich ze wszystkimi”.

Pozycję, miejsce i rolę państwa, czy innego podmiotu, na przykład Unii Europejskiej w systemie międzynarodowym określają jego ustrój, potencjały i prowadzona polityka zagraniczna, a o jej jakości, atrakcyjności i skuteczności decyduje również wiele czynników. Większe możliwości w tym zakresie mają jednak państwa silne, duże, potocznie nazywane imperiami lub mocarstwami. To one de facto prowadzą najbardziej ofensywną politykę zagraniczną i kreują rzeczywistość międzynarodową oraz odgrywają główne role na arenie międzynarodowej. One też ostatecznie przesądzają o kształcie i charakterze powstających systemów (ładów) międzynarodowych. Wyrazem tego są m.in. bilateralne i multilateralne kontakty międzynarodowe, aktywny udział w organizacjach międzynarodowych, członkostwo w sojuszach międzynarodowych oraz podejmowane inicjatywy na rzecz społeczności międzynarodowej. Różna jest skala, zasięg i charakter tego uczestnictwa w życiu międzynarodowym, gdyż różne są racje, interesy i możliwości poszczególnych państw (Łoś-Nowak, 2011, s. 17).

W kontekście powyższego, teoretycznego założenia, współczesne Chiny - moim zdaniem - stoją przed wielką szansą znalezienia się wśród największych potęg świata, które dziś współtworzą nowy ład międzynarodowy, a w przyszłości będą nim zarządzały. Już dziś ChRL zajmuje ważną pozycję na arenie międzynarodowej i odgrywa istotną rolę - obok Stanów Zjednoczonych i Unii Europejskiej - wręcz wiodącą w procesie budowy nowego systemu międzynarodowego (Madison, 2011; Rowiński, 2008, s. 350-351).

Władze w Pekinie zdają sobie sprawę, że po wielu niepowodzeniach, które miały miejsce na przełomie XX i XXI wieku, obecnie prowadzona polityka może okazać się historycznym sukcesem ChRL na arenie międzynarodowej. Bogate w doświadczenia Chiny chcą dzisiaj wykorzystać moment, jaki zrządził im los i w tym wyjątkowym okresie przeprowadzić radykalne zmiany w strukturze gospodarczej i społecznej po to, by dogonić Europę, Japonię i Stany Zjednoczone. Kierując się własnymi interesami narodowymi i aspiracjami międzynarodowymi, Chiny chcą wyprzedzić te kraje pod każdym względem, a zarazem udowodnić własnemu społeczeństwu i całemu światu przewagę chińskiego modelu społeczno-politycznego, gospodarczego i kulturowego. Po cichu marzą o uzyskaniu statusu mocarstwa globalnego, statusu supermocarstwa, które będzie w stanie jeśli nie przejąć kontrolę nad światem, to współrządzić nim wespół z innymi mocarstwami i podmiotami, takimi jak na przykład Unia Europejska. Czy jest to marzenie realne? Wydaje mi się, że tak. Choć jeszcze kilkanaście lat temu taki scenariusz wydawał się niemożliwy do urzeczywistnienia, to dziś już wiadomo, że strategia oparta na konsekwentnym realizowaniu założonych priorytetów spełnia oczekiwania ich władz. My zaś jesteśmy świadkami ponownych „narodzin” chińskiego imperium i uzyskiwania przez Chiny wiodącej roli w świecie.

Nie ulega wątpliwości, że dla Chin XXI wiek upływać będzie pod znakiem coraz silniejszego zaangażowania w światową gospodarkę, a w konsekwencji wzrostu możliwości oddziaływania najpierw w skali regionalnej, później globalnej. Wspomniany kryzys finansowo-gospodarczy, zapoczątkowany w 2008 roku, przyspieszył ten proces, uświadamiając zarówno Pekinowi, jak i wszystkim jego partnerom, że ChRL 
znalazła się na prostej drodze do osiągnięcia statusu mocarstwa światowego. Pod wieloma względami Chiny dziś są po Stanach Zjednoczonych drugą potęgą pierwszą gospodarką mają stać się już za jakąś dekadę. W planach mają dalsze bogacenie się i zdobycie pozycji mocarstwa dominującego w Azji i poza nią.

Dynamicznie rozwijające się Chiny i rosnąca konkurencyjność ich gospodarki stanowią i będą stanowić w najbliższych latach poważne wyzwanie dla dotychczasowych liderów gospodarki światowej. Wydaje się również, iż tak jak dotychczas ważnym instrumentem budowy mocarstwowości ekonomicznej Chin będą narzędzia polityki handlowej. Wspólistnienie multilateralizmu i bilateralizmu z pewnością nadal będzie charakteryzowało politykę handlową tego kraju, a przewaga jednej bądź drugiej strategii będzie wynikała z możliwości jej skutecznego wykorzystania w realizacji celów gospodarczych Chin.

Wzrost pozycji Chin w gospodarce światowej stanowi niewątpliwie ważne wyzwanie dla dotychczasowych potęg gospodarczych. Niewątpliwie sukces gospodarczy Chin i pozycja tego kraju w gospodarce światowej, są efektem reform realizowanych z powodzeniem od końca lat siedemdziesiątych XX wieku i otwarcia na gospodarkę światową. Chiny są przykładem państwa, które w sposób maksymalny wykorzystało efekty procesu globalizacji zainicjowanego przez państwa wysoko rozwinięte. $\mathrm{Na}$ szczególną uwagę zasługują dziś relacje ekonomiczne między Chinami, Stanami Zjednoczonymi i Unią Europejską. Powiązania między tymi podmiotami oddziałują na ich sytuację gospodarczą, a także polityczną. Zarówno Unia Europejska, jak i Chiny wraz ze Stanami Zjednoczonymi osiagnęły status kluczowych podmiotów stosunków międzynarodowych i uczynią wszystko, aby go nie utracić w XXI wieku.

W rywalizacji między Stanami Zjednoczonymi i Chinami o panowanie nad światem większą rolę mogłaby jednak odgrywać Unia Europejska. Tymczasem UE zajęła bardzo ostrożne stanowisko wobec napięć na Morzu Południowochińskim, wywołanych ekspansywnymi działaniami Chin w ostatnich latach, o czym pisałem wcześniej. Taka postawa UE odzwierciedla jej ogólną politykę wobec Azji, która koncentruje się głównie na sprawach gospodarczych i handlowych, a w sferze bezpieczeństwa ogranicza się przede wszystkim do promowania pokojowego rozwiązywania sporów i poszanowania prawa międzynarodowego, a także zaangażowania w niekontrowersyjnych politycznych obszarach, takich jak piractwo, pomoc ofiarom katastrof czy umacnianie pokoju. Takie stanowisko UE jest determinowane też wynikiem różnic zdań w łonie samej Wspólnoty.

Dla Unii Europejskiej, pogrążonej w wewnętrznym kryzysie i stojącej wobec poważnych zagrożeń w swoim najbliższym sąsiedztwie, rosnące napięcia na Morzu Południowochińskim tylko z pozoru mogą wydawać się sprawą o co najwyżej drugorzędnym znaczeniu. $W$ rzeczywistości jednak sytuacja w tym regionie, pomimo geograficznego oddalenia, może negatywnie rzutować na strategiczne interesy UE, bardziej nawet, niż wiele punktów zapalnych na obrzeżach Europy lub w jej pobliżu, które na co dzień przykuwają uwagę państw Wspólnoty. We współczesnym bowiem, zglobalizowanym świecie odległość geograficzna niekoniecznie jest najważniejszym czynnikiem determinującym skalę oddziaływania procesów czy zdarzeń, w tym konfliktów. Dużo ważniejsze jest ich znaczenie ekonomiczne dla regionalnej, jak i globalnej gospodarki, oraz znaczenie geopolityczne, uwidaczniające się między innymi silnym zaangażowaniem mocarstw. 
Nic więc dziwnego, że wielu ekspertów otwarcie zarzuca UE brak ambicji w jej podejściu do kwestii bezpieczeństwa w Azji, proponując jednocześnie szereg działań, które znacząco zwiększyłyby rolę Unii w tym obszarze świata, i nie tylko. Jednakże, pomijając długą listę wyzwań wewnątrz UE i wokół jej granic, często te opinie przeceniają możliwości UE jako aktora na arenie międzynarodowej, jednocześnie niedoceniając zmian, jakie zachodzą w Azji, w tym zwłaszcza w regionie Morza Południowochińskiego. Przez długie lata polityka UE wobec Azji oparta była na założeniu, iż Chiny są - w ramach obecnego porządku światowego - ,usatysfakcjonowanym”, bądź umiarkowanie rewizjonistycznym mocarstwem. Zakładano, że skoro od korzystnych relacji międzynarodowych w dużej mierze zależy dalszy rozwój Chin, będą one ograniczać swoje ambicje terytorialne, lub przynajmniej odkładać ich realizację na dalszy plan. Zgodnie z tą wizją Stany Zjednoczone i UE starały się wspierać budowę wokół stowarzyszenia ASEAN azjatyckiego ładu prawno-instytucjonalnego, odwołując się zresztą do powojennych doświadczeń Europy w tym zakresie, zakładając, że Pekin nie zdecyduje się na otwarte działanie wbrew ustalonym regułom.

Tymczasem polityka Chin wpisuje się w coraz większą liczbę procesów i zdarzeń zwiastujących malejącą rolę reguł i instytucji charakteryzujących liberalny lad międzynarodowy. Ład ten, m.in. ze względu na aktywność rewizjonistycznych mocarstw takich jak Rosja, Chiny czy Iran oraz kryzys świata zachodniego, jest obecnie w odwrocie. Miejsce prawa i organizacji międzynarodowych zajmowane jest przez geopolityczną grę, cechującą się jednostronnymi działaniami i kontr posunięciami mocarstw. Zdaniem wielu obserwatorów, w skali globu w tej grze wiodącą rolę w nadchodzących latach będą odgrywać trzy państwa: Stany Zjednoczone, Chiny oraz, pomimo swej wewnętrznej słabości, Rosja (Kamiński, Szlajfer, 2016; Trenin, 2016). Niestety, UE, pomimo że jest największą gospodarką świata, nie znalazła się w tym gronie z uwagi na problemy wewnętrzne oraz ograniczoną zdolność do występowania jako jednolity aktor na arenie międzynarodowej. Zwłaszcza, jeśli na tej arenie dominuje dziś geopolityczna rywalizacja. Niemniej jednak, UE będzie musiała przystosować się do tej nowej sytuacji. Jej polityka musi z konieczności być jednak skorelowana z poczynaniami innych graczy, zarówno mocarstw, jak i mniejszych państw, a pod tym względem dziś jest wyjątkowo dużo znaków zapytania. Najważniejsze z nich to polityka wobec Azji, a zwłaszcza Chin prezydenta Donalda Trumpa, przyszłe relacje państw azjatyckich, w tym grupy ASEAN, z Waszyngtonem i Pekinem oraz dalsze działania Chin.

\section{Podsumowanie}

Spektakularne sukcesy gospodarcze i w innych dziedzinach życia odnoszone przez ChRL w ostatnich dekadach XX i XXI wieku budzą z jednej strony zachwyt, a z drugiej strony obawy w środowisku międzynarodowym, zwłaszcza wśród dotychczasowych mocarstw na czele ze Stanami Zjednoczonymi. Rodzą wiele pytań, dotyczących przyszłości Chin i ich roli w nowym systemie międzynarodowym. Nie są one też obojętne dla Europy i przemawiającej w jej imieniu na arenie międzynarodowej Unii Europejskiej. Dlatego też problematyka relacji Unii Europejskiej z Chinami dziś i w przyszłości cieszy się tak wielkim zainteresowaniem wśród politologów, ekonomi- 
stów, sinologów, historyków, europeistów i badaczy współczesnych stosunków międzynarodowych. Na temat współczesnych Chin i ich roli na arenie międzynarodowej oraz stosunków z Unią Europejską ukazało się już wiele publikacji na całym świecie, ale wciąż nie wiemy dokąd tak naprawdę zmierzają Chiny i czy Unia Europejska nie rozpadnie się w XXI wieku? Istnieją też wątpliwości odnośnie chińskiego „zwrotu w kierunku multilateralizmu". Według niektórych badaczy ma on całkowicie pozorny charakter i ukryte cele. ChRL bowiem zawsze częściej stosowała strategie bilateralne niż multilateralne w swojej polityce zagranicznej. Jednak w szczególny sposób w XXI wieku praktyka ta stała się widoczna po 2012 roku, tj. od momentu objęcia najwyższej władzy w Chinach przez Xi Jinpinga. Dotyczy to zarówno sfery normatywnej, jak i praktycznej. Xi porzucił „politykę pozostawania w cieniu”, odziedziczoną po Deng Xiaopingu i wyraźnie domaga się globalnego zasięgu, który już nie opiera się na „demokratyzacji stosunków międzynarodowych". Xi już na wstępie oświadczył, że Chiny są globalną potęgą a nie, jak wcześniej nazywano, „potęgą częściową” (Godement, 2016, s. 243; Kwieciński, 2016, s. 9-28).

Xi Jinping postawił sobie ambitne cele i pragnie, aby Chiny zdobyły status mocarstwa globalnego, przewyższającego pod każdym względem Stany Zjednoczone. Pod względem politycznym usiłuje odtworzyć zmilitaryzowaną partię-państwo jako skutecznego budowniczego suwerenności narodowej. Pod względem gospodarczym usiłuje rozwijać Chiny odgórnie zamiast tworzyć indywidualistyczne i innowacyjne społeczeństwo oparte na zrównoważonych instytucjach działających na podstawie zasad legitymizacji. W polityce zagranicznej dąży do opartej na sile polityki sąsiedzkiej, w której Chiny podporządkowują sobie małe kraje w swojej strefie wpływów, oraz do ustalenia relacji „wielkiej potęgi” ze Stanami Zjednoczonymi i Rosją. Co ciekawe, domagając się stosunków „wielkich potęg” ze Stanami Zjednoczonymi, Xi nazywa Rosję ,najważniejszym partnerem strategicznym" Chin (Chiny i Stany Zjednoczone nie nazywają swoich relacji „strategicznym partnerstwem”). Z tego wynika, że prezydent Xi chce połączyć XIX-wieczną geopolitykę z XX-wieczną leninowską polityką, aby zdobyć przewagę w zglobalizowanym świecie XXI wieku. Nasuwa się tutaj pytanie, czy w tej koncepcji Unia Europejska stanie się „strategicznym partnerem” Chin, czy wyznaczono jej rolę drugoplanowa, np. rynku zbytu dla chińskiego przemysłu i handlu?

Relacje między Unią Europejską i Chinami cieszą się też dużym zainteresowaniem w naszym kraju, zwłaszcza po wizycie prezydenta Chin Xi Jinpinga w Polsce w dniach 19-21 czerwca 2016 roku (Winiecki, 2016, s. 46-48; Maciejasz, 2016, s. 13). Chińczycy chca, by Polska otworzyła przed nimi rynki całej Europy, a Polacy - aby Chiny pomogły zbudować nam infrastrukturę i zapewniły kapitał na inwestycje, kiedy po 2020 roku skończą się już unijne fundusze. Polska jest traktowana przez Chińczyków nie tylko jako rynek zbytu, ale też - w kontekście budowy Nowego Jedwabnego Szlaku - jako biznesowy przystanek na drodze Chin do Unii Europejskiej.

\section{Bibliografia}

Abbas N., Förster A., Richter E. (red.) (2015), Supranationalität und Demokratie. Die Europäische Union in Zeiten der Krise, Wiesbaden.

Bielecki J. (2014), Zachodni sojusznicy Putina, „Rzeczpospolita”, 7.05.2014. 
Bielecki T., Zawadzki M. (2016), Unia i NATO postanowity się wzmocnić, „Gazeta Wyborcza”, 9-10.07.2016.

Borkowski K. (2016), Ukraina w kryzysie, w: Procesy europeizacji Ukrainy w wybranych obszarach, red. J. Tymanowski, J. Karwacka, J. Bryl, Kijów-Warszawa.

Buhler P. (2014), O potędze w XXI wieku, Warszawa.

Czaputowicz J. (2007), Teorie stosunków międzynarodowych. Krytyka i systematyzacja, Warszawa 2007.

Donelly J. (2000), Realism and International Relations, Cambridge.

Ein starkes Europa in einer unsicheren Welt von Jean-Marc (2014), strona internetowa Ministerstwa Spraw Zagranicznych RFN.

Fiszer J. M. (2013), System euroatlantycki przed i po zakończeniu zimnej wojny. Istota, cele i zadania oraz rola w budowie nowego ładu globalnego, Warszawa.

Fiszer J. M. (2016), Geopolityczne i geoekonomiczne aspekty europeizacji Ukrainy i jej perspektywy, w: Procesy europeizacji Ukrainy w wybranych obszarach, red. J. Tymanowski. J. Karwacka, J. Bryl, Kijów-Warszawa.

Fiszer J. M. (2014), Czy państwo demokratyczne może być wzorem dla przyszłej Unii Europejskiej?, „Myśl Ekonomiczna i Polityczna”, nr 1(44).

Godement F. (2016), Czego chcq Chiny?, Warszawa.

Grosse T. G. (2016), Kryzys po Brexicie, „Rzeczpospolita”, 15.07.2016.

Góralczyk B. (2015), W poszukiwaniu chińskiego modelu rozwojowego, „Sprawy Międzynarodowe", $\mathrm{nr} 2$.

Heise H. (2014), Europa nach der Krise. Die Währungsunion vollenden, Wiesbaden.

Guzek M. (2014), Kapitalizm na krawędzi, Warszawa.

Kamiński A. Z., Szlajfer H. (2016), Śmiertelnie niebezpieczny trójkat, „Rzeczpospolita”, 20 X 2016.

Korzycki R. (2017), Po szczycie G7. Trump nie da rady zniszczyć klimatu. Dzięki Obamie, „Gazeta Wyborcza", 29.05.2017.

Kuźniar R. (2016), Europa w porządku międzynarodowym, Warszawa.

Kuźniar R. (2015), Ukraine - Europe's hic Rhodus, hic salta, w: European Union on the Global Scene: united or Irrelevant?, red. B. J. Góralczyk, Warsaw.

Leonard M. (2008), What Does China Think, London.

Kwieciński R. (2016), Bilateralizm i multilateralizm w polityce zagranicznej Chińskiej Republiki Ludowej, w: Chiny i świat zewnętrzny, red. J. Marszałek-Kawa, Torun.

Łoś R. (2017), Soft Power Chin, „Studia Polityczne”, t. 45, nr 1.

Łoś-Nowak T. (2011), Polityka zagraniczna w przestrzeni teoretycznej, w: Polityka zagraniczna. Aktorzy, potencjały, strategie, red. T. Łoś-Nowak, Warszawa.

Maciejasz D. (2016), Biznes z Chinami na jednym szlaku, „Gazeta Wyborcza”, 21.06.2016.

Maddison A. (2011), The Word Economy: A Millennial Perspectiv, Paryż.

„Myśl Ekonomiczna i Polityczna” (2014), nr 3(46).

„Przegląd Politologiczny” (2016), nr 1.

Radziwinowicz W. (2016), Odwilż rosyjsko-turecka, „Gazeta Wyborcza”, 7.07.2016.

Rowiński J. (2008), Chiny: nowa globalna potęga? Cień dawnej świetności i lat poniżenia, w: Dokad zmierza świat?, red. A. D. Rotfeld, Warszawa.

Ruszkowski J., Wojnicz L. (red.) (2013), Multi-Level Governance w Unii Europejskiej, SzczecinWarszawa.

Stiglitz J. (2017), Lekcja angielskiego, Obserwator finansowy.pl, https://www.obserwatorfinansowy. $\mathrm{pl} /$ tematyka/makroekonomia/lekcja. 
„Studia Polityczne” (2014), nr 4(36).

„Studia Europejskie” (2014), nr 4(72).

Szczerski K. (2017), Utopia Europejska. Kryzys integracji i polska inicjatywa naprawy, Kraków.

Szpak A. (2015), Kryzys migracyjny w Europie a bezpieczeństwo - podtoże społeczno-ekonomiczne, zagrożenia, pomoc rozwojowa, „Sprawy Międzynarodowe”, $\mathrm{nr} 2$.

Szymańska A. (2016), Europa dziennikarzy, Kraków.

Świder K. (2015), Rosyjska świadomość geopolityczna a Ukraina i Białoruś (po rozpadzie Zwiazku Radzieckiego), Warszawa.

Trenin D. (2016), Three powers will shape future state of Word, „China Daily”, 31 X 2016.

Warszawski D. (2017), Trump igra z wojnq, „Gazeta Wyborcza”, 20.05.2017.

Wieliński B. T., Wroński P., Zawadzki M. (2016), Ukraina bez zmian, Gruzja rozczarowana, „Gazeta Wyborcza", 11.07.2016.

Wieliński B. T. (2016), Nasza siła odstraszania rośnie. Rozmowa z Radosławem Sikorskim, „Gazeta Wyborcza", 7.07.2016.

Wierzchowska A. (2016), Wpływ modernizacji i kryzysu na dynamikę zmiany w Unii Europejskiej, Warszawa.

Winiecki J. (2016, s. 13), Uszczelnianie granic. W Warszawie NATO musi zdecydować nie tylko jak i przed kim, ale także czego i jakich wartości chce bronić, „Polityka”, 6-12.07.2016.

Winiecki J. (2016), Chiński podziat Europy, „Polityka”, 22-28.06.2016.

Wojciechowski S., Tomczak M. (red.) (2010), Mocarstwowość na przełomie XX i XXI w. Teorie-analizy-programy, Poznań.

Wroński P. (2016), Rosja już mniej groźna. Przebudzenie NATO, „Gazeta Wyborcza”, 11.07.2016.

Załęcki Ł., Borkowski P. J., Wróbel A. (2013), Wewnętrzne uwarunkowania aktywności międzynarodowej Chińskiej Republiki Ludowej i jej relacji z Uniq Europejskq, Warszawa.

Zakaria F. (2009), Koniec hegemonii Ameryki, Warszawa.

Żakowski J. (2016), Czas satrapów i nielotów, „Polityka”, 27.07-2.08.2016.

\section{Streszczenie}

Nie ulega wątpliwości, że zarówno Unia Europejska, jak i Chiny odgrywają dziś - obok Stanów Zjednoczonych - główne role na arenie międzynarodowej. We wzajemnych relacjach mają status partnerów strategicznych i starają się rozwijać współpracę we wszystkich dziedzinach, ale też występują między nimi różnice zdań i stanowisk w wielu istotnych sprawach. Na łamach niniejszego artykułu próbuję pokazać przesłanki, szanse i zagrożenia dla obu tych aktorów na arenie międzynarodowej oraz ich wzajemne relacje dziś i w przyszłości. Ponadto próbuję zweryfikować kontrowersyjną - moim zdaniem - hipotezę, lansowaną przez wielu badaczy, a która zakłada, że wiek XXI będzie wiekiem Azji, czyli de facto Chin.

Na temat współczesnych Chin i ich roli na arenie międzynarodowej oraz stosunków z Unią Europejską ukazało się już dużo publikacji na całym świecie, ale wciąż nie wiemy dokąd tak naprawdę Chiny zmierzają i czy Unia Europejska nie rozpadnie się w XXI wieku? Istnieją też wątpliwości odnośnie chińskiego „Zwrotu w kierunku multilateralizmu”. Zdaniem niektórych badaczy, ma on całkowicie pozorny charakter i służy tylko do kamuflowania dalekosiężnych celów ChRL, czyli przejęcia przez nią kontroli nad światem w drugiej połowie XXI wieku.

Słowa kluczowe: Chiny, Unia Europejska, współpraca, stosunki międzynarodowe, multipolarny świat, Brexit, XXI wiek 


\section{EU-China Relations in the 21st Century}

\section{Summary}

Today, EU and China - along the US - undoubtedly play a key role in the international arena. They have established strategic partnership in their bilateral relations and strive to develop cooperation in all areas. Yet, they also dissent on many important issues. In this article, I investigate the premises of EU-China bilateral relations, as well as opportunities and threats to both parties as far as their status on the global stage is concerned. Moreover, I test the thesis I deem controversial, which claims that the $21^{\text {st }}$ century will be Asian century, and de facto the era of China.

The literature on contemporary China, on the role it plays in the international arena and on its relations with the EU is abundant. However no definite answer has been given yet as to where China is heading and whether rhe EU will break up in the $21^{\text {st }}$ century. China's "turn to multilateralism" is questioned, with some researchers claiming that it simply serves to conceal China's long-term goal, i.e. taking control over the world in the second half of the $21^{\text {st }}$ century.

Key words: China, European Union, cooperation, international relations, multipolar world, Brexit, $21^{\text {st }}$ century 
